\title{
Restaurant Cooking Trends and Increased Risk for Campylobacter Infection
}

\author{
Anna K. Jones, Dan Rigby, ${ }^{1}$ Michael Burton, Caroline Millman, Nicola J. Williams, Trevor R. Jones, \\ Paul Wigley, Sarah J. O’Brien, Paul Cross'; for the ENIGMA Consortium
}

In the United Kingdom, outbreaks of Campylobacter infection are increasingly attributed to undercooked chicken livers, yet many recipes, including those of top chefs, advocate short cooking times and serving livers pink. During 2015, we studied preferences of chefs and the public in the United Kingdom and investigated the link between liver rareness and survival of Campylobacter. We used photographs to assess chefs' ability to identify chicken livers meeting safe cooking guidelines. To investigate the microbiological safety of livers chefs preferred to serve, we modeled Campylobacter survival in infected chicken livers cooked to various temperatures. Most chefs correctly identified safely cooked livers but overestimated the public's preference for rareness and thus preferred to serve them more rare. We estimated that $19 \%-52 \%$ of livers served commercially in the United Kingdom fail to reach $70^{\circ} \mathrm{C}$ and that predicted Campylobacter survival rates are $48 \%-98 \%$. These findings indicate that cooking trends are linked to increasing Campylobacter infections.

$F$ oodborne illness is very costly, comprising medical expenses, loss of earnings, and reduced quality of life. In the United States, the annual healthcare cost is $\approx \$ 14$ billion annually (1); in the United Kingdom, it is $£ 1.8$ billion (2). The foodborne illness most commonly responsible for these costs is campylobacteriosis (3-5). In the United States, cases increased by 13\% between 2006-2008 and 2013 (6). In the United Kingdom, Campylobacter accounted for over half of the estimated 500,000 cases of foodborne disease during 2011-2012 (3,7); in the United States, it accounts for $9 \%$ of foodborne disease cases annually (4).

Foods implicated as Campylobacter vehicles include poultry, red meat, milk, and water (7-11). Studies of outbreaks and sporadic cases have identified the principal source of infection as undercooked chicken meat (9-14).

Author affiliations: Bangor University, Bangor, Wales, UK

(A.K. Jones, P. Cross); University of Manchester, Manchester, UK (D. Rigby, M. Burton, C. Millman); University of Liverpool, Neston, UK (N.J. Williams, T.R. Jones, P. Wigley, S.J. O'Brien)

DOI: http://dx.doi.org/10.3201/eid2207.151775
In the United Kingdom, increasing numbers of outbreaks are attributed to undercooked chicken livers (9) despite the fact that the UK Food Standards Agency (FSA) has provided guidelines for safely cooking them. These increased infections seem to have coincided with a trend among leading chefs to advocate minimal cooking of chicken livers, despite recommendations to maintain liver cores at $70^{\circ} \mathrm{C}$ for $2-3$ minutes to ensure they are Campylobacter free (15).

Although the association between consuming chicken livers and infection with Campylobacter is well known (9), the underlying reasons for the changing epidemiology of outbreaks associated with chicken liver consumption are unclear. We hypothesized that the trend toward including rarer, pinker meat in the recipes of leading chefs and by mass media representation of meat cooking may be contributing to changes in the way chicken livers are consumed.

We therefore conducted an interdisciplinary investigation by using a combination of methods from social and biological sciences. Participants were selected from the UK population, and the study was conducted during 2015. Our study objectives were 1) to investigate the ability of chefs and members of the public to identify cooked chicken livers that meet FSA guidelines for safe cooking, 2) to elicit the preferences of chefs and the public regarding the rareness of chicken livers, and 3) to model the survival of Campylobacter in chicken livers sautéed to various core temperatures.

\section{Methods}

\section{Participants}

We recruited a quota-based sample of 1,030 members of the UK public via an online market research panel (http:// www.researchnow.com). Quotas were used to ensure representativeness in terms of age groups and social class. The quota permitted an unequal split by sex (up to $70 \%$ women) because in the United Kingdom, food preparation at home

\footnotetext{
${ }^{1}$ These senior authors contributed equally to this article.
} 
is more commonly performed by women than men. We also recruited 143 chefs through face-to-face convenience sampling at culinary shows and competitions and by online culinary forums.

All participants gave informed consent. Respondents were debriefed on the purpose of the survey after completion and given the opportunity to withdraw their data. Ethical approval was obtained from the College of Natural Science Ethics Committee at Bangor University (CNS/2014/AJ1).

\section{Preparation of Visual Aids}

To prepare cooked chicken liver dishes to serve as visual aids, we used methods similar to those used in studies of hamburgers (16) and beefsteaks (17). A chef cooked 7 batches of chicken livers for various times, recorded the maximum core temperature for each batch, and arranged each batch on a plate for photography by a professional photographer. The process was repeated (without the temperature being recorded) for 3 other meats (duck breasts, lamb racks, and beef burgers).

\section{Surveys of Preference and Knowledge}

To determine preferences and knowledge of safe cooking practices among chefs and members of the public, we used the images of cooked chicken livers as visual aids. The images were presented in surveys (online and print), arranged in order of cooking time/rareness (Figure 1). The surveys for chefs and the public were similar, except that the chefs were asked about serving preferences and the public was asked about eating preferences.
To avoid biases (such as social desirability bias) resulting from respondents perceiving the survey to be about food safety, we described the survey as being about food preferences. Respondents were first asked preference questions about 3 of the 4 meats (in random order) to obscure the focus on chicken livers and safety. Chefs were asked to indicate which chicken liver dish was cooked "the way you would like to serve it" and "the way you think most customers would like it." Members of the public were asked which dish they would prefer if "eating out" and "eating at home."

Respondents were subsequently asked which chicken liver dish (if any) was the first they thought would meet FSA safe cooking guidelines. Additional questions were asked about perceived trends and influences regarding cooking meat, dining habits, and demographic information such as class and age. Chefs provided additional information about their current position, such as their training and industry experience.

\section{Campylobacter Survival}

To prepare a suspension of Campylobacter for experimental inoculation, we streaked Camplyobacter jejuni M1 strain (sequence type 137, clonal complex 45) on Columbia agar base containing 5\% defibrinated horse blood, incubated it at $37^{\circ} \mathrm{C}$ under microaerobic conditions for 48-72 h, and then inoculated it into Camplyobacter enrichment broth. After subculture for another $24 \mathrm{~h}$, a bacterial suspension was prepared in maximum recovery diluent to an optical density of $600 \mathrm{~nm}\left(\approx 10^{9} \mathrm{CFU} / \mathrm{mL}\right)$. The culture broth was diluted in Camplyobacter enrichment

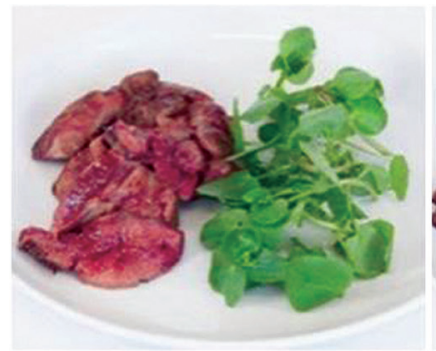

Liver 1

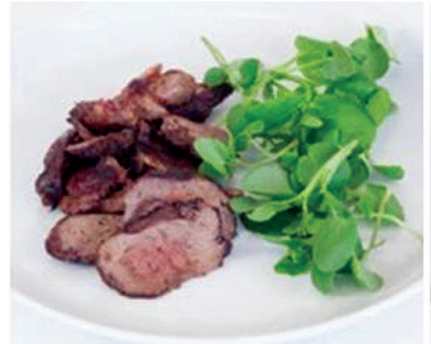

Liver 5

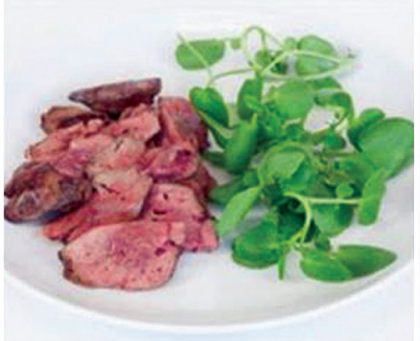

Liver 2

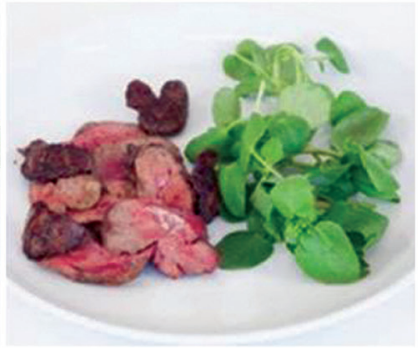

Liver 3

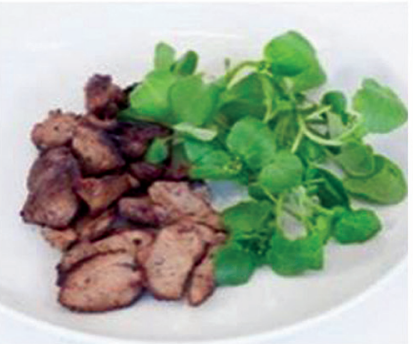

Liver 6

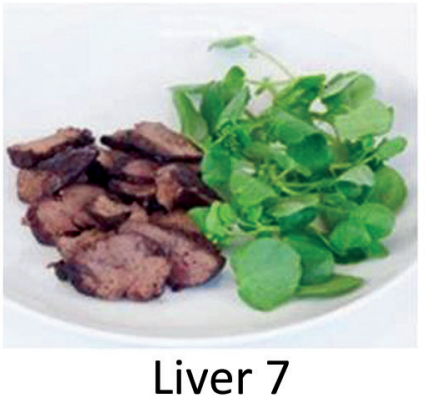

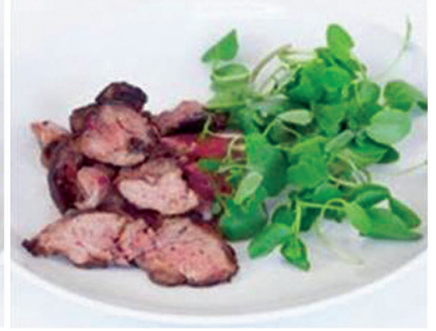

Liver 4

Figure 1. Chicken liver images, in order of cooking time/rareness, used in survey to determine preferences and knowledge of safe cooking practices among chefs and the public, United Kingdom. 
broth to give a suspension of $\approx 10^{5} \mathrm{CFU} / \mathrm{mL}$ for inoculation into fresh chicken livers.

The fresh chicken livers were purchased in packs from supermarkets and sorted into batches of 4 with similar weights. The connective tissue was cut between the 2 liver lobes, with the weight of the larger lobe recorded and assigned for inoculation with Campylobacter broth suspension; 4 livers were assigned to each cooking batch. A $1-\mathrm{cm}^{2}$ area of each liver was scored at its thickest point by using a sterile scalpel blade and injected with $100 \mu \mathrm{L}\left(\approx 10^{4}\right.$ CFU) of culture broth, corresponding to the highest levels of Campylobacter reported to be found in naturally contaminated livers (18).

For each cooking time, $10 \mathrm{~g}$ butter was heated in a frying pan over moderate to high heat on an electric cooktop; when the butter had finished frothing, the 4 inoculated liver lobes in the batch were added. The maximum core temperature of the largest and smallest liver in each batch was recorded. To determine the survival of the inoculated M1 strain of $C$. jejuni within the cooked livers, we placed each liver in a sterile petri dish, and a 4-5-g portion around the scored inoculated region was removed and added to a Stomacher bag (Seward BA6040, Worthing, UK); $10 \mathrm{~mL}$ of Exeter broth was added to each bag before Stomaching (mechanical pounding of the outer surface of the bag to remove bacteria) for $1 \mathrm{~min}$. The homogenized suspension was poured into a $20-\mathrm{mL}$ universal container and incubated at $41^{\circ} \mathrm{C}$ under microaerobic conditions (Variable Atmosphere Incubator; Don Whitely Scientific, Shipley, UK) for $24 \mathrm{~h}$, after which 1 loopful of broth was plated onto Campylobacter blood-free medium (modified charcoal cefoperazone deoxycholate agar, containing cefoperazone and amphotericin) at $41^{\circ} \mathrm{C}$ under microaerobic conditions for 48-72 h. We picked 1 typical Campylobacter colony from at least 1 plate in each batch and confirmed it as $C$. jejuni by PCR; for a cooked liver to be deemed positive, 1 isolate per batch was confirmed as C. jejuni positive (19).

\section{Data Analyses}

We modeled the probability of survival for the 60 livers for which temperature and Campylobacter presence/absence after cooking were recorded. We used logistic regression to model the relationship between the core temperature of the livers and the survival of Campylobacter. The probability of Campylobacter survival as a function of core temperature was modeled via estimation of a logit model, which captured the nonlinear temperature-survival relationship (Figure 2). Parameter estimates were obtained by using logistic regression (Stata logit command; StataCorp LP, College Station, TX, USA) on the binary variable indicating Camplyobacter survival $(1=$ survival, $0=$ nonsurvival $)$ in a sample of 60 cooked chicken livers. Temperature was the maximum core temperature recorded for the batch from which the chicken liver was taken. This model was used to assign predicted survival rates for each photographed chicken liver dish.

We used the Kolmogorov Smirnov 2-sample test to compare differences in the distribution of knowledge and preferences between groups (chefs and the public). We investigated within-person differences by using the Wilcoxon signed-rank test for paired data. Ordered logit models (20) were estimated to determine the effects of observable characteristics on respondents' preferences for chicken liver rareness and their choices of FSA-compliant livers.

\section{Results}

\section{Campylobacter Survival}

We discuss the results of the Campylobacter survival experiment first because an understanding of those results is useful for interpreting the preferences and knowledge analyses. The relationship between core temperature and Campylobacter survival rate was inverse (Table; Figure 2). Of the 32 batches of 4 inoculated livers, the shortest cooking time was 1 minute, leading to a mean core temperature of $36^{\circ} \mathrm{C}$ and a $100 \%$ Campylobacter survival rate. At the maximum mean core temperature $\left(72^{\circ} \mathrm{C}\right)$, Campylobacter survival rate was $8.3 \%$.

The logistic model predicted a survival rate of $98 \%$ in liver with core temperature that reached $52^{\circ} \mathrm{C}$ (liver 1) and equivalent survival rates of $95 \%$ and $48 \%$ at core temperatures of $56^{\circ} \mathrm{C}$ and $66^{\circ} \mathrm{C}$ (livers 2 and 3). Liver 4 reached a maximum temperature of $70^{\circ} \mathrm{C}$, but the temperature was not held for the recommended 2 minutes; predicted Campylobacter survival rate was $22 \%$. Livers 6 and 7 met the FSA guidelines, and their predicted Campylobacter survival rate was $<0.001 \%$.

\section{Preferences and Knowledge of the Public}

Of the 1,030 members of the public surveyed, $43.0 \%$ ate chicken livers and hence were asked to select the chicken

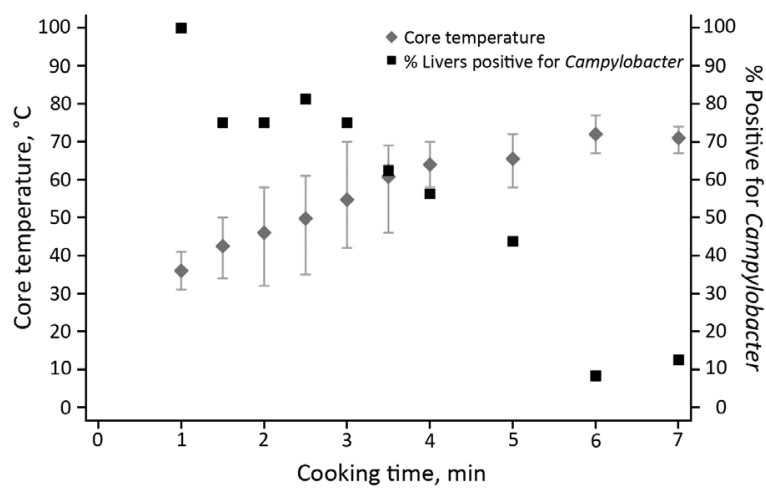

Figure 2. Campylobacter survival in cooked (pan-fried) chicken livers, by cooking time and temperature. Error bars represent minimum and maximum temperatures reached. 
Table. Campylobacter survival in cooked chicken liver, by replicate*

\begin{tabular}{|c|c|c|c|c|c|c|c|c|c|c|}
\hline \multirow[b]{2}{*}{ Variable } & \multicolumn{10}{|c|}{ Cooking time, $\min$} \\
\hline & 1 & 1.5 & 2 & 2.5 & 3 & 3.5 & 4 & 5 & 6 & 7 \\
\hline \multicolumn{11}{|l|}{ Replicate 1} \\
\hline No. positive & 4.0 & 3.0 & 3.0 & 3.0 & 4.0 & 3.0 & 2.0 & 3.0 & ND & ND \\
\hline Mean weight, g & 41.5 & 41.5 & 43.8 & 41.5 & 41.5 & 41.5 & 40.3 & 40.8 & ND & ND \\
\hline Mean core temp, ${ }^{\circ} \mathrm{C}$ & 36.0 & 46.0 & 44.0 & 41.0 & 47.5 & 55.5 & 60.5 & 61.5 & ND & ND \\
\hline \multicolumn{11}{|l|}{ Replicate 2} \\
\hline No. positive & ND & 3.0 & 3.0 & 4.0 & 3.0 & 3.0 & 3.0 & 3.0 & 0 & ND \\
\hline Mean weight, $\mathrm{g}$ & ND & 34.0 & 34.0 & 34.0 & 34.3 & 34.0 & 34.3 & 34.5 & 34.3 & ND \\
\hline Mean core temp, ${ }^{\circ} \mathrm{C}$ & ND & 39.0 & 42.5 & 44.0 & 50.5 & 59.0 & 65.5 & 65.0 & 72.0 & ND \\
\hline \multicolumn{11}{|l|}{ Replicate 3} \\
\hline No. positive & ND & ND & 2.0 & 4.0 & 4.0 & 4.0 & 3.0 & 3.0 & 1.0 & 1.0 \\
\hline Mean weight, $\mathrm{g}$ & ND & ND & 40.0 & 40.3 & 39.3 & 40.5 & 40.5 & 40.3 & 39.5 & 39.0 \\
\hline Mean core temp, ${ }^{\circ} \mathrm{C}$ & ND & ND & 41.5 & 55.5 & 57.5 & 61.0 & 69.0 & 64.0 & 69.0 & 72.5 \\
\hline \multicolumn{11}{|l|}{ Replicate 4} \\
\hline No. positive & ND & ND & 4.0 & 2.0 & 1.0 & 0.0 & 1.0 & 1.0 & 0 & 0 \\
\hline Mean weight, g & ND & ND & 25.8 & 26.3 & 28.0 & 26.5 & 27.3 & 24.8 & 27.8 & 29.5 \\
\hline Mean core temp, ${ }^{\circ} \mathrm{C}$ & ND & ND & 56.0 & 58.5 & 63.5 & 67.5 & 61.0 & 71.5 & 75.0 & 69.5 \\
\hline No. livers & 4 & 8 & 16 & 16 & 16 & 16 & 16 & 16 & 12 & 8 \\
\hline No. positive & 4 & 6 & 12 & 13 & 12 & 10 & 9 & 10 & 1 & 1 \\
\hline Mean no. positive per batch of 4 & 4.0 & 3.0 & 3.0 & 3.3 & 3.0 & 2.5 & 2.3 & 2.5 & 0.3 & 0.5 \\
\hline Overall mean $\%$ of positives & 100 & 75.0 & 75.0 & 81.3 & 75.0 & 62.5 & 56.3 & 62.5 & 8.3 & 12.5 \\
\hline Overall mean liver weigh, $\mathrm{g}$ & 41.5 & 37.8 & 35.9 & 35.5 & 35.8 & 35.6 & 35.6 & 35.1 & 33.8 & 34.3 \\
\hline Overall mean core temperature, ${ }^{\circ} \mathrm{C}$ & 36.0 & 42.5 & 46.0 & 49.8 & 54.8 & 60.8 & 64.0 & 65.5 & 72.0 & 71.0 \\
\hline
\end{tabular}

liver dishes they preferred and which they thought met FSA guidelines. Half $(49.3 \%)$ of all male respondents and $38.4 \%$ of all female respondents ate chicken livers. Rates of chicken liver consumption varied by age group: $18-34$ years, $34.7 \%$; 35-44 years, $44.7 \%$; 45-54 years, $49.0 \%, 55-64$ years: $51.5 \%$; and $\geq 65: 42.9 \%$. Chicken livers were eaten by half $(51.0 \%)$ of respondents belonging to UK socioeconomic grouping $\mathrm{ABC} 1$ (upper, middle, and lower middle class) and $32.3 \%$ of those belonging to $\mathrm{C} 2 \mathrm{DE}$ (working class and those at the lowest level of subsistence).

Members of the public poorly identified whether a chicken liver met FSA guidelines for safe cooking (Figure 3 ). Thirty percent identified livers $1-3$ as being safe to eat; the predicted rates of Campylobacter survival in these livers were $48 \%-98 \%$. Another $22 \%$ thought that liver 4 (Campylobacter survival rate 22\%) was safe to eat.

No significant difference was found between the public's choices of FSA-compliant livers and their preferences when dining out $(\mathrm{p}=0.776$, Wilcoxon signedrank test; $n=386$ ) (Figure 4); respondents were consistent between what they wanted to eat and what they thought was safe. Respondents showed a significant preference for pinker livers when eating out rather than at home $(\mathrm{p}=$ 0.007 , Wilcoxon signed-rank test; $n=446$ ). Paradoxically, respondents reported being more concerned about food safety when eating out than at home $(\mathrm{p}<0.001$, Wilcoxon signed-rank test; $\mathrm{n}=999$ ).

Ordered logit results (not reported) identified no systematic differences in rareness preferences by respondent sex, age, or class. Livers that were more pink were preferred by respondents who described themselves as adventurous $(\mathrm{p}<0.030, \mathrm{n}=444)$ and who were less concerned about restaurant food safety $(\mathrm{p}<0.001, \mathrm{n}=444)$.

\section{Perceptions and Knowledge of Chefs}

Among the 143 chefs, of those who indicated their sex, $134(88 \%)$ were male. Among the 141 who indicated their type of work, $31.9 \%$ worked in fine dining, $17 \%$ in contract catering, $11.3 \%$ in casual restaurants, $5.7 \%$ in pubs, and $19.1 \%$ in multiple kitchen types. The most commonly held position among 131 chefs who responded was head chef $(54.0 \%)$, followed by chef trainer $(11.5 \%)$, chef de partie $(10.7 \%)$, commis chef $(6.9 \%)$, and sous chef $(6.1 \%)$.

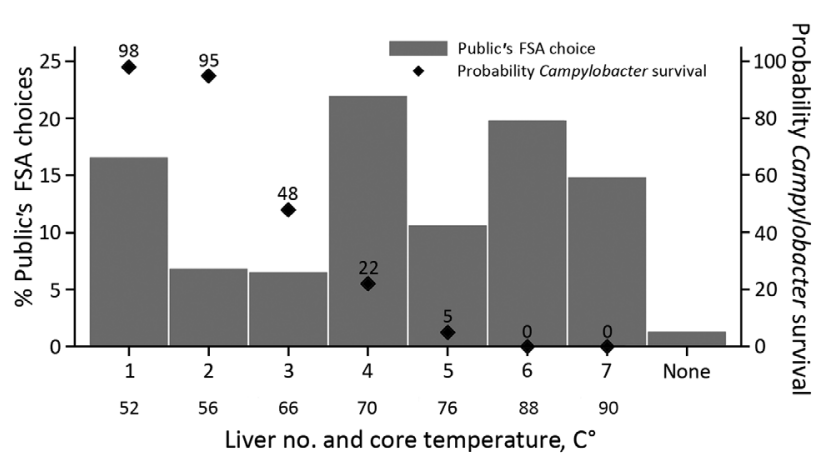

Figure 3. Rarest chicken livers visually identified by members of the public as complying with FSA cooking guidelines and associated core temperatures and probabilities of Campylobacter survival in survey to determine preferences and knowledge of safe cooking practices among chefs and the public, United Kingdom. Liver image numbers correspond to those shown in Figure 1. FSA, Food Standards Agency. 


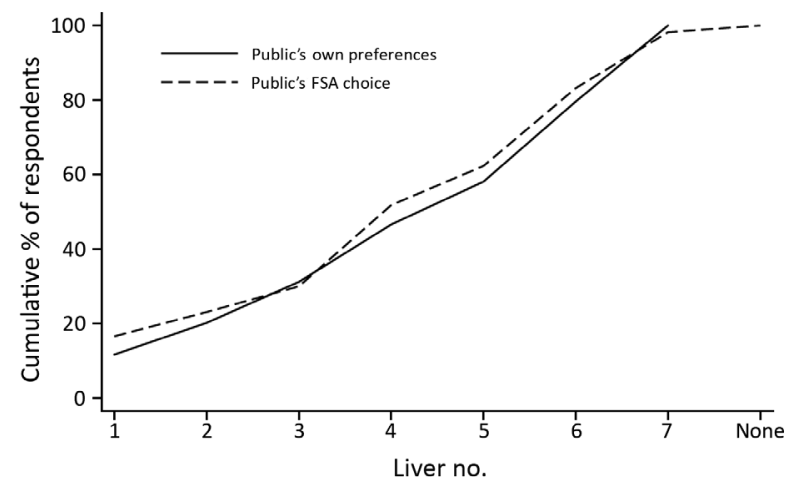

Figure 4. Proportion of public identifying which chicken liver dishes they preferred and which they believed complied with FSA cooking guidelines in survey to determine preferences and knowledge of safe cooking practices among chefs and the public, United Kingdom. Liver image numbers correspond to those shown in Figure 1. FSA, Food Standards Agency.

Chefs were much better than members of the public at identifying whether a chicken liver met FSA guidelines; only $9.8 \%$ of chefs (vs. $30 \%$ of the public) selected livers $1-3$ as being FSA compliant (Figure 5), and another $19.8 \%$ thought that liver 4 met FSA guidelines. Although they outperformed the public, $30 \%$ of the chefs identified livers with Campylobacter survival rates of $22 \%-98 \%$ as being FSA compliant.

Chefs preferred to serve livers more pink than they thought would meet FSA guidelines $(\mathrm{p}<0.001$, Wilcoxon signed-rank test; $\mathrm{n}=143$ ) (Figure 5). Chefs also preferred to serve livers substantially more pink than the public preferred when eating out $(\mathrm{p}<0.001$, Kolmogorov-Smirnov 2 -sample test). Chefs' perceptions of customers' preferences for rareness differed significantly from customer's true preferences: not only did chefs prefer to serve livers more rare than customers wanted them served, they also thought that customers wanted chicken livers more rare than the customers themselves indicated ( $p=0.008$, KolmogorovSmirnov 2-sample test).

As with the members of the public, in the ordered logit model to explain serving preferences, chef preference for pinkness of served livers did not vary according to chef characteristics such as age, sex, and class. The only significant results indicated that chefs holding senior positions preferred to serve liver more pink than did their less experienced colleagues holding junior kitchen positions $(\mathrm{p}=0.002)$.

\section{Culinary Trends}

Almost half (47.8\%) of the members of the public sampled agreed that "cooking programmes on $\mathrm{TV}$ and/or recipes in magazines have influenced the way the general public cook meat, people now serve it pinker in the middle." Among chefs, $>45 \%$ agreed that they had noticed a trend of rarer and pinker chicken livers on television, in recipes, and among other chefs.

\section{Discussion}

Members of the public poorly identified whether chicken livers had been cooked to a safe microbiological state. Their preferences for chicken livers were consistent with their (often inaccurate) perceptions of safely cooked livers. Among chefs, these variables differed; chefs outperformed the public at identifying whether chicken livers had been cooked to FSA guidelines. We found that chef preferences for serving chicken livers were inconsistent with their perceptions of safe cooking - they preferred to serve livers more rare than is microbiologically safe and believed that their customers also prefer them more rare than is safe. Chefs systematically overpredicted their customers' preferences for pinkness of livers served. This finding probably means that an estimated $19 \%-52 \%$ of livers being served in commercial UK food establishments fail to reach a core temperature of $70^{\circ} \mathrm{C}$ and could have Campylobacter survival rates of $48 \%-98 \%$.

Chefs preferred rarer livers than the FSA guidelines would recommend. Chefs (correctly) thought that customers preferred livers less rare than their own preferences ( $p<0.001$, Wilcoxon signed-rank test), but they still overestimated customers' preference for pinkness. Chefs' preferences, rather than their ignorance of FSA microbiological guidelines, seem to be leading them to serve undercooked livers. This finding resonates with previous findings that knowledge is not necessarily a driver of behavior (21-23). We contend that the explanation for the discrepancy between cooking practices and recommended guidelines is a cultural one, resulting in preferences for taste and texture overriding the desire to avoid foodborne illness (24-26). In extremis, this preference ultimately led chef Raymond

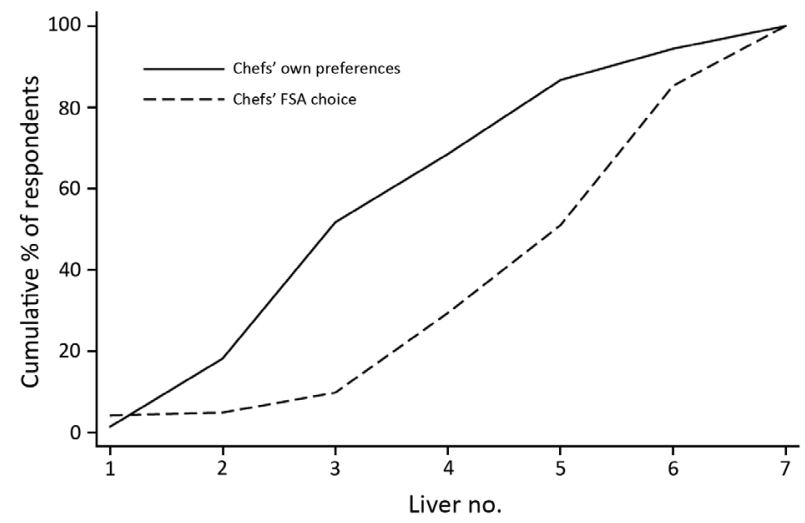

Figure 5. Proportion of chefs identifying which chicken liver dishes they preferred and which they believed complied with FSA cooking guidelines in survey to determine preferences and knowledge of safe cooking practices among chefs and the public, United Kingdom. Liver image numbers correspond to those shown in Figure 1. FSA, Food Standards Agency. 
Blanc to remove liver dishes from the menu rather than increase cooking times/temperatures after cases of campylobacteriosis were attributed to diners having eaten liver in his restaurant (27).

The public health implications of the contrast between chef preferences and safe practices depend largely on what chefs provide for customers. Given that chefs prefer livers more pink than they believe customers do, we take the chef perception of customer preference as the lower bound and chefs' own preference as the upper bound on the rareness of chicken livers served. This finding implies that $18.9 \%-51.7 \%$ of livers being served in commercial UK food establishments are failing to reach a core temperature of $70^{\circ} \mathrm{C}$ and have Campylobacter survival rates of $48 \%-98 \%$ (Figure 6 ). Extending the range of livers considered unsafe to liver 4 from our testing implies that $38.5 \%-68.5 \%$ of chicken livers being served commercially may have Campylobacter survival rates of $22 \%-98 \%$.

This preference for rare chicken livers is part of a broader shift in contemporary cooking culture toward rarer meats, a trend that is reflected in the mass media $(28,29)$ but not yet in the peer-reviewed literature. Periodically, the preference among chefs for serving rarer meat results in conflicts with recommendations of public health officials (30-32). The trend toward serving meat more pink has now extended from meats such as beefsteaks to meats such as chicken livers, for which the microbiological risks associated with rareness are far greater.

Our interdisciplinary approach, using relatively large samples of chefs and members of the general public, provides a unique insight into the possible public health implications of a divergence between preferences and safe cooking. A limitation of our approach is basing selection of preferred dishes on visual inspection alone. However, an experimental design that enabled respondents to

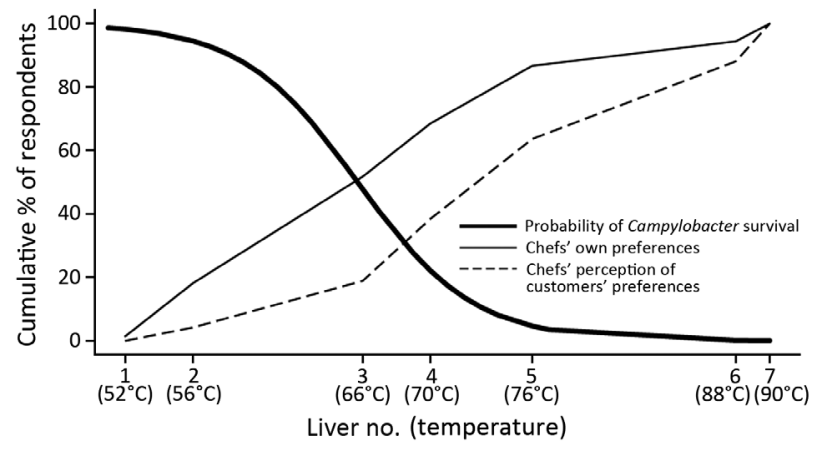

Figure 6. Proportion of chefs identifying which chicken liver dishes they preferred and which they believed their customers would prefer and associated probabilities of Campylobacter survival in survey to determine preferences and knowledge of safe cooking practices among chefs and the public, United Kingdom. Liver image numbers correspond to those shown in Figure 1. physically assess cooked dishes would have severely limited study size. Another limitation is use of a laboratorycultured inoculum, which might be less heat resistant than naturally occurring bacteria. Therefore, the projected death rates might be overestimated, and undercooked livers might pose even more of a risk than this study suggests. Our results relate to the C. jejuni M1 strain only; other Campylobacter strains may exhibit different survival characteristics. Campylobacter survival is reported here in terms of presence or absence, not as colony counts. Results indicate public risk for exposure to Campylobacter, not risk for infection or subsequent illness. The low doses required for infection and illness $(33,34)$ are part of a stochastic process that can happen at any dose, suggesting that the presence of any Campylobacter in cooked livers poses a public health threat.

Because all experimental livers were inoculated with Campylobacter, our results have been framed in terms of probability of Campylobacter survival rather than exposure. Hence, our reported rates at which chefs serve Camplyobacter-positive livers may be slightly overestimated.

The temperature-survival results presented here, supported by those of Whyte et al. (15), suggest that the chicken liver cooking techniques practiced by many chefs, and promoted in the culinary and mass media, are leading to increased exposure to Campylobacter. The role of celebrity chefs and the mass media in pushing the trend toward serving pink meat were evident in our results. Recipes by top chefs frequently recommend serving chicken livers pink in the middle in warm salads, pâtés, and parfaits $(35,36)$. This trend toward pink resonates with our estimate, based on our survey and experimental results, that $19 \%-52 \%$ of livers served in UK food outlets do not reach a core temperature of $70^{\circ} \mathrm{C}$ and our predicted Campylobacter survival rates of 48\%-98\%. Given Campylobacter prevalence rates among UK retail chicken livers ( $81 \%-100 \%$ externally, $90 \%$ internally $[15,37])$, our results suggest that contemporary cooking trends are leading to the "gourmet-fication" of foodborne disease.

\section{Acknowledgments}

We acknowledge the Medical Research Council, Natural Environment Research Council, Economic and Social Research Council, Biotechnology and Biosciences Research Council, and Food Standards Agency for the funding received for this project (ENIGMA) through the Environmental \& Social Ecology of Human Infectious Diseases Initiative, grant reference G1100799/1.

Dr. Jones is a research officer at the School of Environment, Natural Resources and Geography, Bangor University, Wales. Her research interests focus on food security and sustainability along the supply chain. 


\section{References}

1. Hoffmann S, Batz MB, Morris JJ. Annual cost of illness and quality-adjusted life year losses in the United States due to 14 foodborne pathogens. J Food Prot. 2012;75:1292-302. http://dx.doi.org/10.4315/0362-028X.JFP-11-417

2. Food Standards Agency. Annual report of the chief scientist 2012/13. Safer food for the nation. London: The Agency; 2013.

3. Tam CC, Rodrigues LC, Viviani L, Dodds JP, Evans MR, Hunter PR, et al. Longitudinal study of infectious intestinal disease in the United Kingdom (IID2 study): incidence in the community and presenting to general practice. Gut. 2012;61:69-77. http://dx.doi.org/10.1136/gut.2011.238386

4. Scallan E, Hoekstra RM, Angulo FJ, Tauxe RV, Widdowson MA, Roy SL, et al. Foodborne illness acquired in the United Statesmajor pathogens. Emerg Infect Dis. 2011;17:7-15. http://dx.doi.org/10.3201/eid1701.P11101

5. Kirk MD, Pires SM, Black RE, Caipo M, Crump JA, Devleesschauwer B, et al. World Health Organization estimates of the global and regional disease burden of 22 foodborne bacterial, protozoal, and viral diseases, 2010: a data synthesis. PLoS Med. 2015;12:e1001921. http://dx.doi.org/10.1371/ journal.pmed.1001921

6. Crim SM, Iwamoto M, Huang JY, Griffin PM, Gilliss D, Cronquist $\mathrm{AB}$, et al. Incidence and trends of infection with pathogens transmitted commonly through food-Foodborne Diseases Active Surveillance Network, 10 U.S. sites, 2006-2013. MMWR Morb Mortal Wkly Rep. 2014;63:328-32.

7. Tam C, Larose T, O'Brien S. Costed extension to the second study of infectious intestinal disease in the community: identifying the proportion of foodborne disease in the United Kingdom and attributing foodborne disease by food commodity. Report no.: Project B18021 (FS231043). London: Food Standards Agency; 2014.

8. Frost JA, Gillespie IA, O'Brien SJ. Public health implications of Campylobacter outbreaks in England and Wales, 1995-9: epidemiological and microbiological investigations. Epidemiol Infect. 2002;128:111-8. http://dx.doi.org/10.1017/ S0950268802006799

9. Little CL, Gormley FJ, Rawal N, Richardson JF. A recipe for disaster: outbreaks of campylobacteriosis associated with poultry liver pâté in England and Wales. Epidemiol Infect. 2010;138:16914. http://dx.doi.org/10.1017/S0950268810001974

10. Humphrey T, O'Brien S, Madsen M. Campylobacters as zoonotic pathogens: a food production perspective. Int J Food Microbiol. 2007;117:237-57. http://dx.doi.org/10.1016/j.jffoodmicro.2007.01.006

11. Adak GK, Meakins SM, Yip H, Lopman BA, O’Brien SJ. Disease risks from foods, England and Wales, 1996-2000. Emerg Infect Dis. 2005;11:365-72. http://dx.doi.org/10.3201/eid1103.040191

12. Butzler JP. Campylobacter, from obscurity to celebrity. Clin Microbiol Infect. 2004;10:868-76. http://dx.doi.org/10.1111/ j.1469-0691.2004.00983.x

13. Sheppard SK, Dallas JF, Strachan NJC, MacRae M, McCarthy ND, Wilson DJ, et al. Campylobacter genotyping to determine the source of human infection. Clin Infect Dis. 2009;48:1072-8. http://dx.doi.org/10.1086/597402

14. Domingues AR, Pires SM, Halasa T, Hald T. Source attribution of human campylobacteriosis using a meta-analysis of case-control studies of sporadic infections. Epidemiol Infect. 2012;140:970-81. http://dx.doi.org/10.1017/S0950268811002676

15. Whyte R, Hudson JA, Graham C. Campylobacter in chicken livers and their destruction by pan frying. Lett Appl Microbiol. 2006; 43:591-5. http://dx.doi.org/10.1111/j.1472-765X.2006.02020.x

16. Røssvoll EH, Lavik R, Ueland Ø, Jacobsen E, Hagtvedt T, Langsrud S. Food safety practices among Norwegian consumers. J Food Prot. 2013;76:1939-47.

17. López Osornio MM, Hough G, Salvador A, Chambers E IV, McGraw S, Fiszman S. Beef's optimum internal cooking temperature as seen by consumers from different countries using survival analysis statistics. Food Qual Prefer. 2008;19:12-20. http://dx.doi.org/10.1016/j.foodqual.2007.06.004

18. Baumgartner A, Felleisen R. Market surveillance for contamination with thermotolerant campylobacters on various categories of chicken meat in Switzerland. J Food Prot. 2011; 74:2048-54. http://dx.doi.org/10.4315/0362-028X.JFP-11-228

19. Klena JD, Parker CT, Knibb K, Ibbitt JC, Devane PM, Horn ST, et al. Differentiation of Campylobacter coli, Campylobacter jejuni, Campylobacter lari, and Campylobacter upsaliensis by a multiplex PCR developed from the nucleotide sequence of the lipid A gene lpxA. J Clin Microbiol. 2004;42:5549-57. http://dx.doi.org/ 10.1128/JCM.42.12.5549-5557.2004

20. Greene WH. Econometric analysis. 7th ed. Harlow (UK): Pearson Education Limited; 2011. p. 926.

21. Levy AS, Choinière CJ, Fein SB. Practice-specific risk perceptions and self-reported food safety practices. Risk Anal. 2008;28:749-61. http://dx.doi.org/10.1111/j.1539-6924.2008.01051.x

22. Olsen NV, Røssvoll E, Langsrud S, Scholderer J. Hamburger hazards and emotions. Appetite. 2014;78:95-101. http://dx.doi.org/ 10.1016/j.appet.2014.03.007

23. Green Brown L, Khargonekar S, Bushnell L; The Environmental Health Specialists Network Working Group. Frequency of inadequate chicken cross-contamination prevention and cooking practices in restaurants. J Food Prot. 2013;76:2141-5. http://dx.doi.org/10.4315/0362-028X.JFP-13-129

24. McIntosh WA, Christensen LB, Acuff GR. Perceptions of risks of eating undercooked meat and willingness to change cooking practices. Appetite. 1994;22:83-96. http://dx.doi.org/10.1006/ appe.1994.1007

25. Ralston K, Brent CP, Starke Y, Riggins T, Jordan Lin CT. Consumer food safety behavior: a case study in hamburger cooking and ordering. Agricultural Economic Report no. 804. Washington (DC): US Department of Agriculture; 2001. p. 11-2.

26. O'Leary MC, Harding O, Fisher L, Cowden J. A continuous common-source outbreak of campylobacteriosis associated with changes to the preparation of chicken liver pâte. Epidemiol Infect. 2009;137:383-8. http://dx.doi.org/10.1017/S0950268808001003

27. Davies C. Raymond Blanc ordered to take lamb's liver off menu after food poisoning [cited 2015 May 6]. http://www.theguardian.com/ lifeandstyle/2012/nov/13/raymond-blanc-lambs-liverfood-poisoning

28. Morris S. Bloody marvellous: how did we fall in love with rare meat? [cited 2015 May 6]. http://www.independent.co.uk/ life-style/food-and-drink/features/bloody-marvellous-how-did-wefall-in-love-with-rare-meat-6294303.html

29. Winter G. Celebrity chefs are trying to make undercooked pork fashionable. But could it kill you? [cited 2015 May 6]. http://www.dailymail.co.uk/health/article-1202601/Celebrity-chefstrying-make-undercooked-pork-fashionable-But-kill-you.html

30. Copping J, Malnick E. Chefs defy health inspectors over rare meat [cited 2015 May 6]. http://www.telegraph.co.uk/ foodanddrink/10249764/Chefs-defy-health-inspectors-overrare-meat.html.

31. Doward J. Chefs fight for the right to serve their pork pink [cited 2015 May 6]. http://www.theguardian.com/lifeandstyle/2013/ sep/21/chefs-pork-pink

32. Fagge N. How health police are making rare steaks rarer: Prue Leith says officials are enforcing rules designed for factories to ensure meat is cooked through [cited 2015 May 6]. http://www.dailymail.co.uk/news/article-2396605/Prue-Leithwarns-rare-steak-rarer-restaurants-councils-demands.html

33. Black RE, Levine MM, Clements ML, Hughes TP, Blaser MJ. Experimental Campylobacter jejuni infection in humans. J Infect Dis. 1988;157:472-9. http://dx.doi.org/10.1093/ infdis/157.3.472 
34. Teunis P, Van Den Brandhof W, Nauta M, Wagenaar J, Van Den Kerkhof H, Van Pelt W. A reconsideration of the Campylobacter dose-response relation. Epidemiol Infect. 2005;133:583-92. http://dx.doi.org/10.1017/ S0950268805003912

35. Kerridge T. Tom Kerridge's proper pub food. Bath (UK): Absolute Press; 2013. p. 49.

36. Oliver J. Jamie's kitchen. London: Penguin Books Limited; 2010. p. 204-5.
37. Strachan NJC, MacRae M, Thomson A, Rotariu O, Ogden ID, Forbes KJ. Source attribution, prevalence and enumeration of Campylobacter spp. from retail liver. Int J Food Microbiol. 2012; 153:234-6. http://dx.doi.org/10.1016/j.ijfoodmicro.2011.10.033

Address for correspondence: Sarah J. O'Brien, Institute of Infection and Global Health, University of Liverpool, Liverpool L69 7BE, UK; email: s.j.obrien@liverpool.ac.uk

\section{February 2016: Ebola}

\section{Including:}

- Randomized Controlled Trial of Hospital-Based Hygiene and Water Treatment Intervention (CHoBl7) to Reduce Cholera

- Epidemiology of Epidemic Ebola Virus Disease in Conakry and Surrounding Prefectures, Guinea, 2014-2015

- Hospital Preparations for Viral Hemorrhagic Fever Patients and Experience Gained from the Admission of an Ebola Patient

- Prognostic Indicators for Ebola Patient Survival

- Invasive Group A Streptococcus Infection among Children, Rural Kenya

- Trematode Fluke Procerovum varium as Cause of Ocular Inflammation in Children, South India

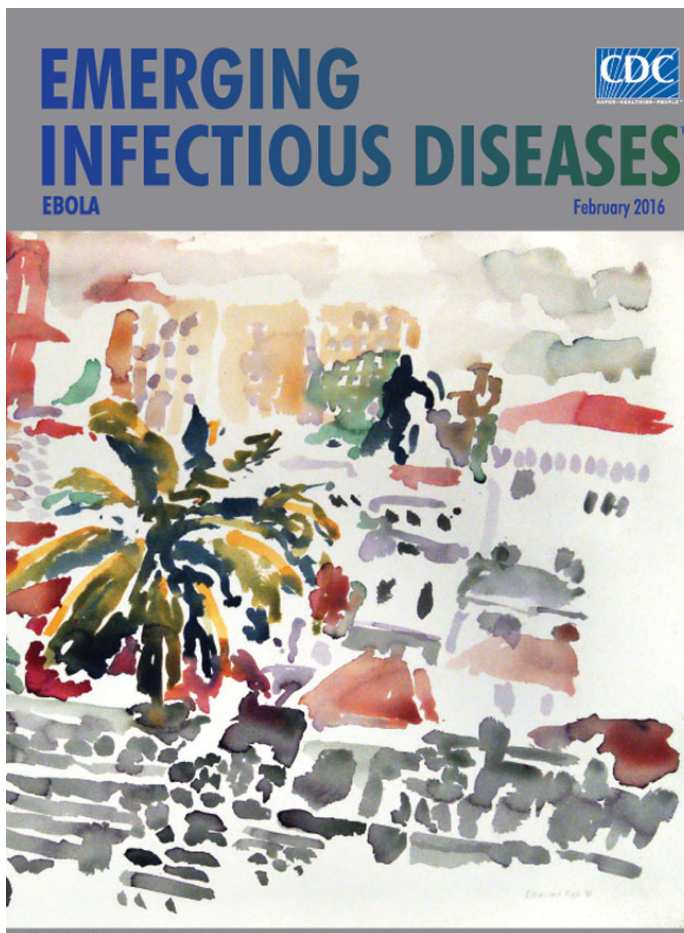

- Association between Landscape Factors and Spatial Patterns of Plasmodium knowlesi Infections in Sabah, Malaysia

- Feasibility of Xpert Ebola Assay in Médecins Sans Frontières Ebola Program, Guinea

- Sustained Transmission of Pertussis in Vaccinated, 1-5-Year-Old Children in a Preschool, Florida, USA

- Molecular Characterization of Invasive Streptococcus dysgalactiae subsp. equisimilis, Japan

- Population Effects of Influenza A(H1N1) Pandemic among Health Plan Members, San Diego, California, USA, October-December 2009

$\bullet$

- Ebola and Its Control in Liberia, 2014-2015

http://wwwnc.cdc.gov/eid/articles/issue/22/02/table-of-contents 